\title{
Genetic Control of Ovarian Development
}

\author{
S.G. Tevosian \\ Department of Physiological Sciences, College of Veterinary Medicine, University of Florida, Gainesville, Fla., USA
}

\author{
Key Words \\ $\beta$-Catenin · Development · FOXL2 - Granulosa • Mammals · \\ Ovary $\cdot$ Somatic $\cdot$ WNT4
}

\begin{abstract}
During embryonic development, ovarian somatic cells embark on a course that is separate from male somatic cells and from indifferent precursor cells. While the former aspect of ovarian development is well known, the latter has not received much attention until recently. This review attempts to integrate the most recent work regarding the differentiation of ovarian somatic cells. The discussion of the parallel development of the testis is limited to the key differences only. Similarly, germ cell development will be introduced only inasmuch as it becomes necessary to draw attention to a particular aspect of the somatic component differentiation. Finally, while postnatal ovarian development and folliculogenesis undoubtedly provide the ultimate morphological and functional fitness tests for the ovarian somatic cells, postnatal phenotypes will be only referred to when they have already been connected to genes that are expressed during embryogenesis.

Copyright $\odot 2012$ S. Karger AG, Basel
\end{abstract}

Sexual development in most mammals is genetically determined by the inheritance of the father's Y chromosome by male, but not female, offspring at fertilization. Despite this initial fundamental and irreversible com- mitment, the sex determination program remains latent, and male (XY) and female (XX) embryos are morphologically indistinguishable during their early development. In both sexes, the bipotential (indifferent) gonads arise from the urogenital ridges that appear on the surface of the mesonephroi, which are bilateral rudimentary nephric primordia that lie laterally to the differentiating gonad. At a specific developmental stage, the male and the female pathways diverge: the XY gonadal anlagen differentiate into testes and the XX anlagen form ovaries. This sex determination step in male mammals is initiated by Sry (sex-determining region of chromosome Y), the $\mathrm{Y}$ chromosome-linked testis-determining gene. Triggered by SRY, the formation of testes from the bipotential embryonic gonad, rather than ovaries, is considered to be the decisive step for subsequent male sexual development [reviewed in Swain and Lovell-Badge, 1999; Capel, 2000; Wilhelm et al., 2007; Combes et al., 2010]. Given that the majority of the functional genetic data has been obtained through gene manipulation in mice, they will be used as the main reference species for further discussion. Nevertheless, studies of disorders of sexual development (DSD) in humans and in other species (e.g. goat) have been very valuable towards our understanding of ovarian development, and these will be considered as well.

The discovery that testis determination in mammals is contingent on the presence of the $\mathrm{Y}$ chromosome provided further support for a model where the process of ovarian differentiation occurs by default, unless it is redirected by the $\mathrm{Y}$ chromosome to make a testis [Jost,

\section{KARGER \\ Fax +4161306 1234 \\ E-Mail karger@karger.ch}

www.karger.com
(C) 2012 S. Karger AG, Basel

$1661-5425 / 13 / 0073-0033 \$ 38.00 / 0$

Accessible online at:

www.karger.com/sxd
Sergei G. Tevosian

Department of Physiological Sciences, College of Veterinary Medicine

University of Florida, 1333 Central Drive

Gainesville, FL 32601 (USA)

Tel. +1 352294 4364, E-Mail stevosian@ufl.edu 


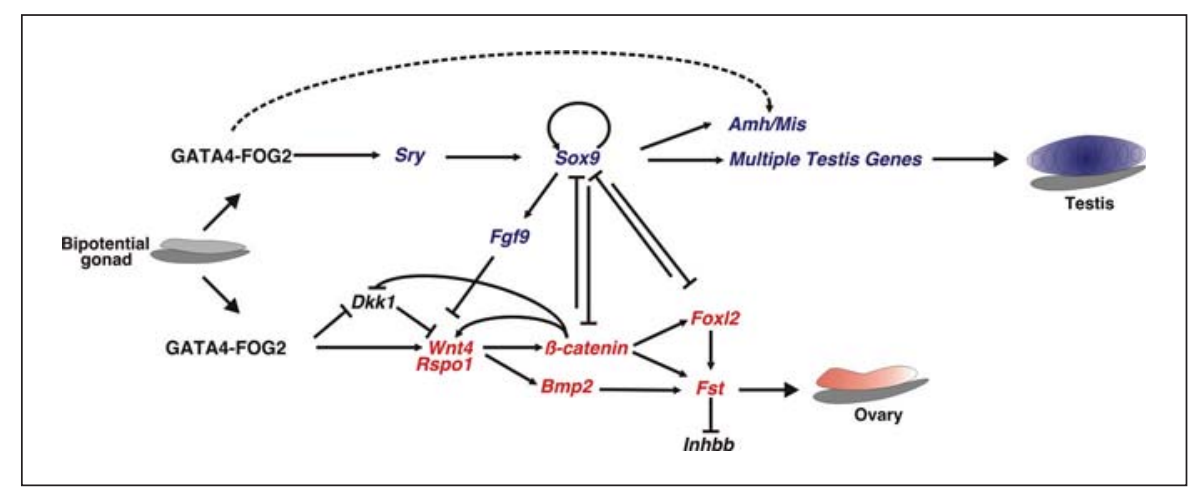

Fig. 1. The outline of the regulatory network that controls gonadal embryonic development in mice. During ovarian sex determination, the GATA4-FOG2 transcriptional complex regulates the canonical $\mathrm{Wnt} / \beta$-catenin pathway at least in 2 ways: activation of Wnt4 gene expression as well as the repression of the $D k k 1$ gene that encodes for an inhibitor of this pathway. WNT4 and RSPO1 likely work together to activate the canonical $\beta$-catenin pathway in the somatic cells of the ovary. Wnt4 is also required for Bmp2 expression. $\beta$-catenin induces expression of $W n t 4$ in a positive

1972; Burgoyne, 1988; Goodfellow and Darling, 1988]. The isolation of Sry [Gubbay et al., 1990; Sinclair et al., 1990; Koopman et al., 1991] was the seminal step that provided a solid genetic foundation for the subsequent 20 years of molecular analysis of male sexual development. The parsimonious concept of a single switch that alone controls cell fate was affirmed in testis development, where a sole gene (i.e. Sry or later its direct target Sox9) is sufficient for sex determination [Koopman et al., 1991; Bishop et al., 1999; Vidal et al., 2001; Sekido and LovellBadge, 2008]. Similarly, in the absence of SRY or SOX9 function, the bipotential gonad develops as an ovary [Koopman et al., 1991; Chaboissier et al., 2004; Barrionuevo et al., 2006].

The cases of XY sex reversal in the presence of Sry (XY females, e.g. B6-YPOS) [Eicher et al., 1982] or SRY-negative $\mathrm{XX}$ sex reversal (XX males) could formally be explained within the framework of the 'default' pathway. However, an alternative mechanism that would allow for a more prominent role for the female-specific genes appeared at least equally attractive. Not surprisingly, the 'master gene' paradigm influenced the quest for a similar omnipotent determinant of ovarian destiny. It was proposed, variously, that such a hypothetical gene could either independently initiate ovarian development (the concept of the 'ovarian determinant', pioneered by Eva Eicher) [Eicher and Washburn, 1983; Washburn and Eicher, 1983; Eicher and Washburn, 1986] or suppress the default ge- feedback loop and suppresses expression of Sox9. $\beta$-catenin, FOXL2, and BMP2 cooperate in activating the expression of Fst. FST antagonizes the action of Inhbb to suppress the emergence of the testis-specific vasculature and acts to support female germ cells. The antagonism between SOX9/FGF9-regulated and Wnt/ RSPO1/ $\beta \beta$-catenin-regulated pathways is emerging as a key element in the tug-of-war battle of the sexes during embryonic development, while FOXL2 versus DMRT1 antagonism is important in the adult. netic pathways leading to testis formation (dubbed 'factor Z') [McElreavey et al., 1993]. In this latter model, the antagonistic nature of male and female determinants (as well as their downstream targets) is explicitly emphasized [Ottolenghi et al., 2007a]. To date, the precise genetic mechanism of sexual development is still enigmatic for mammalian females. While no complete XX sex reversal has been described in recessive mouse models, the possibility remains that a single, yet unidentified, gene controls ovarian sex determination. In recent years, however, the notion of an ovarian counterpart to Sry gave way to a less stringent hypothesis, where more than one gene is involved in the initial commitment to the ovarian fate. Several combinations have been postulated and will be discussed below. While the argument for a collective hypothesis of ovarian determination appears persuasive, it remains to be proven conclusively, and the precise gene combination that unlocks the ovarian fate remains unknown.

Currently, the notion that the embryonic ovary engages in active gene regulation appears almost mundane. However, sexually dimorphic gene expression in the somatic cells of the embryonic ovary has only been identified fairly recently [Menke and Page, 2002]. It is widely believed that the genetic programs of male and female development are closely intertwined and that the 2 alternative fates are likely to be determined by antagonistic activities. Experimental evidence suggests that the pro- 
cess of dimorphic gonadal development is initiated in a limited number of cells by sex-specific transcription factors and is then expanded by extracellular, non-cell-autonomous signals that promote one developmental program while suppressing the other (fig. 1) [Palmer and Burgoyne, 1991; Goodfellow and Lovell, 1993; Brennan and Capel, 2004; Wilhelm et al., 2005; Capel, 2006; Kim and Capel, 2006; Kim Y et al., 2006].

\section{Ovarian Cells and Their Function throughout Development}

The 2 main roles of the ovary are the production of steroid hormones and the generation of mature oocytes [reviewed in Edson et al., 2009; Richards and Pangas, 2010]. The follicle is the functional unit of the adult ovary; it is comprised of a mature oocyte that is surrounded by supporting granulosa cells (the female counterpart of Sertoli cells) and the steroidogenic theca cells (the female counterpart of adult Leydig cells). The formation of testis cords in mice refers to the stereotypic rearrangement of the somatic Sertoli cells to enclose the gonocytes at embryonic day (E) 12.5. This extensive structural reorganization clearly demarcates the commencement of male differentiation. Unlike this comprehensive transformation of the male gonad, the female organ does not undergo dramatic morphological changes until close to birth. One should not infer, however, that the embryonic ovary remains dormant. At the molecular and cellular level, it has long been known that the embryonic ovary engages in robust dimorphic activity, with ovarian germ cells (the oogonia) beginning to enter meiosis at E12.5 [reviewed in Byskov, 1986; McLaren and Southee, 1997; Byskov and Nielsen, 2003]. In addition, confocal analysis shows that the poorly differentiated XX gonad undergoes some remodeling between E13.5 and E15.5, when the primordial germ cells develop as interconnected cysts/clusters that are linked by cytoplasmic bridges [Gondos and Zamboni, 1969; Pepling and Spradling, 1998]. While segmentation into the cortex and medulla is not morphologically apparent in mice during embryogenesis, these areas are definable by gene expression as early as E12.5. Specifically, cells in the sub-coelomic (cortex) area express Bmp2 (see below), while the central (medulla) area expresses markers normally associated with pre-granulosa cells: Wnt4, Fst, and Foxl2.

The granulosa cells of the developing ovary are somatic cells that are derived from the same progenitor population as the Sertoli cells of the testis [Burgoyne et al., 1988;
McLaren, 1991; Albrecht and Eicher, 2001]. In agreement with their pre-Sertoli/pre-granulosa status, these cells residing in the medullar area also express the Sry-Egfp transgene (Tg92) [Albrecht and Eicher, 2001]. Specifically, Albrecht and Eicher [2001] generated a transgenic mouse line $\mathrm{Tg} 92$ in which EGFP expression was driven by proximal $\sim 8 \mathrm{~kb}$ of $S r y$ promoter elements (Sry-Egfp). The EGFP expression pattern in XY transgenic embryos resembled endogenous Sry expression. In addition, EGFP expression from the transgene was detected in a subset of somatic cells in the medullar region of the XX gonad, indicating that both testis and ovary contained primed cell populations capable of activating the Sry gene promoter. The authors proposed that a $S r y$-Egfp-expressing population had acquired the competence to differentiate into the supporting cell lineage from which both Sertoli and granulosa cells are derived. In contrast to the XY cells that down-regulate Sry-Egfp concomitantly with the endogenous Sry expression at E12.5, the XX cells retained reporter activity after the time of birth. Similar results were obtained in a lineage mapping experiment using a 9.9-kb Sry-promoter driven Cre line, with activated reporter activity still detectable in the ovary 2 weeks after birth and restricted to a subset of descendant granulosa cells [Ito et al., 2006].

A recent work re-evaluated the commitment of XX Sry-Egfp-expressing cells in Tg92 animals to granulosa cell fate and demonstrated that in E12.5-E13.5 embryos these cells are also positive for the granulosa cell marker, FOXL2 [Mork et al., 2011]. While this observation further ascertained pre-granulosa status of the XX Sry-expressing cells, it was also noted that EGFP-positive and FOXL2positive populations in the ovary did not completely overlap. This suggested the heterogeneous nature of embryonic cells that gave rise to pre-granulosa lineage.

The relationship between these domains of embryonic gene expression and the cortex/medulla domains of the adult ovary is not yet clear. However, in both aforementioned experiments that capitalized on the opportune competence of granulosa cell precursors to express Sry, only a small fraction of granulosa cells retained detectable EGFP expression after the time of birth. Capel and colleagues took these observations further by showing that contribution of the embryonic bipotential supporting cell precursors to postnatal ovary was limited [Mork et al., 2011]. The rare descendants of embryonic precursors were scattered among non-labeled granulosa cells and confined to a specific subset of medullar follicles that began to grow immediately after birth. Using a tamoxifen-inducible Foxl2-Cre transgenic line, the authors 
traced the origin of the precursor cells to the proliferative ovarian surface epithelium. In contrast, granulosa cells in the cortical primordial follicles (that ultimately constitute the adult follicular supply) appeared instead to derive from the surface epithelium between the time of birth and postnatal day $(\mathrm{P}) 7$. These observations introduce a previously underappreciated possibility that the majority of granulosa cells in the adult ovary originate from cells other than their embryonic counterpart. It is important to keep the perspective that different floxed loci exhibit differential susceptibility to Cre recombination which may have a substantial impact on the outcome of fate mapping experiments [Vooijs et al., 2001; Ma et al., 2008]. It will be interesting to explore this tantalizing hypothesis further (for example by using inducible Foxl2-driven Cre line with reporter strains other than R26RLacZ) [Novak et al., 2000; Vooijs et al., 2001; Ma et al., 2008].

In contrast to female germ cells, the pre-granulosa and other somatic populations of the embryonic ovary have not received sufficient attention until recently. This relative neglect is normally attributed to a lack of discernable elements when compared to the multitude of events that are characteristic of early testis development such as cord formation, robust cellular proliferation, steroidogenesis, and prominent vascular development [reviewed in Brennan and Capel, 2004; Munger et al., 2009]. While the validity of this assumption is debatable, it is indisputable that a major breakthrough in identifying female-specific gene expression as early as E11.5 became possible with the advent of differential RNA expression screening, particularly microarray technology [Menke et al., 2003; Yao et al., 2004; Jorgensen and Gao, 2005; Nef et al., 2005; Small et al., 2005; Beverdam and Koopman, 2006; Cederroth et al., 2007; Lee et al., 2008].

\section{Genetic Mechanisms of Ovarian Development}

\section{Genetic Regulators of Ovarian Development}

Gata4/6 and Fog2

The transcription factors of the GATA family (GATA binding proteins 4 and 6) and their co-factor FOG2 (Zfpm2, zinc finger protein, multitype 2) have been implicated as key drivers of multiple developmental processes [Molkentin, 2000; Patient and McGhee, 2002; Morceau et al., 2004; Viger et al., 2008]. Ovarian sexual development is dramatically affected by the loss of the GATA4FOG2 interaction. One of the roles of the GATA4-FOG2 complex is to serve as a repressor for the $D k k 1$ gene that encodes a secreted inhibitor of canonical $\beta$-catenin sig- naling (see below) [Manuylov et al., 2008]. The role of the GATA family proteins in sex determination and gonadal differentiation has recently been the subject of an extensive review [Zaytouni et al., 2011] and hence will not be duplicated here.

\section{Foxl2 (Forkhead Box L2)}

The forkhead transcription factor Foxl2 can be detected in the developing XX gonad in mice as early as E11.5 [Wilhelm et al., 2009], making it one of the earliest markers of a commitment to granulosa cell fate in the supporting cell lineage. Foxl2 expression continues throughout the subsequent ovarian development in somatic granulosa and theca cells of all the follicular stages [Schmidt et al., 2004]. FOXL2 was briefly considered to be the longsought-after female-determining factor because of its association with female-to-male sex reversal in polled intersex syndrome goats [Pailhoux et al., 2001] and its conserved ovarian expression pattern in several vertebrates [Loffler et al., 2003; Wang et al., 2004]. However, subsequent studies did not support this seminal role for FOXL2 in early ovary organogenesis, at least in humans and in mice. Human patients carrying mutations in the FOXL2 gene display blepharophimosis, ptosis and epicanthus inversus syndrome, an autosomal disease characterized by eyelid defects and premature ovarian failure in females, but no sex reversal [Townes and Muechler, 1979; Crisponi et al., 2001; Pailhoux et al., 2001]. Similarly, ablation of the Foxl2 gene in mice leads to a block in the squamousto-cuboidal transition of the postnatal granulosa cells. The impaired differentiation of Foxl2 $2^{-/}$granulosa cells leads to a premature depletion of the primordial follicle pool and infertility. In contrast to the profoundly disabled follicular development, the embryonic appearance of the ovary in Foxl2 null females is unremarkable, with no indications of cord formation or other fundamentals of testis development [Schmidt et al., 2004; Uda et al., 2004]. Ectopic expression of Foxl2 in XY transgenic mice impaired the differentiation of the testis cords [Ottolenghi et al., 2007b]; this experiment demonstrated the antitestis properties of Foxl2 but provided no evidence for concomitant ovarian differentiation. While the preponderance of data did not support the crowning of FOXL2 as the sole ovarian determinant, subsequent research confirmed the pivotal role of this transcription factor in maintaining ovarian identity as described below [for recent reviews, see Schlessinger et al., 2010; Uhlenhaut and Treier, 2011]. 
Wnt4 (Wingless-Related MMTV Integration Site 4)

WNT4 belongs to a family of 19 secreted proteins that play key roles during development, including embryonic organogenesis, the generation of cell polarity, and cell differentiation in vertebrates. WNT proteins are known to activate 3 discrete pathways upon binding to different WNT receptors: the canonical Wnt/ $\beta$-catenin cascade, the non-canonical planar cell polarity (PCP) pathway, and the Wnt $/ \mathrm{Ca}^{2+}$ pathway [reviewed in Katoh, 2005; Kohn and Moon, 2005; Huang and He, 2008]. The canonical Wnt/ $\beta$-catenin pathway is central to the embryonic development of the mammalian ovary and will be considered in greater detail in the following section. At the bipotential stage, low levels of Wnt4 expression are present in both XY and XX gonads. This expression becomes female-specific by E12.5. Female embryos lacking functional WNT4 exhibit several notable defects in their sexual development, including a rounded testis-like shape of the gonad, the emergence of androgen-producing cells, the appearance of male-specific structures at birth, and the loss of female germ cells (oogonia) beginning at E15.5 [Vainio et al., 1999]. Further work highlighted additional features of Wnt4 deletion and firmly put this gene in the center of the genetic network regulating ovarian development. In the female, WNT4 prevents the formation of a male-specific coelomic blood vessel and the production of steroids [Jeays-Ward et al., 2003; Jordan et al., 2003]. A duplication of WNT4 in an XY sexreversed patient has been described [Jordan et al., 2001]. Similarly, a heterozygous mutation in WNT4 results in an excess of androgen and an absence of the uterus (an atypical Mayer-Rokitansky-Küster-Hauser-like syndrome) [Biason-Lauber et al., 2004, 2007], while a homozygous loss of function mutation leads to a severe SERKAL (female sex reversal and dysgenesis of kidneys, adrenals, and lungs) syndrome (fetal lethality and testes or ovotestes in XX fetuses) [Mandel et al., 2008]. It is of note that the histological appearance of the testes in a 19-week-old 46 ,XX fetus with a homozygous WNT4 mutation was characterized as 'normal-looking' [Mandel et al., 2008], suggesting that (similarly to Rspo1/RSPO1, see below) the degree of sex-reversal could be more complete in humans than in Wnt4 null mice [Vainio et al., 1999].

The work of McMahon and colleagues identified the role of WNT4 in the ovary in the late 90s [Stark et al., 1994; Vainio et al., 1999]. One might think that establishing the mechanistic connection to the canonical $\beta$-catenin pathway in the ovary was straightforward from that point on. However, it took almost a decade before this connection was established. One can only speculate why it took so long for such a connection to be made; perhaps an emphasis was simply not placed on the study of ovarian development at the time. Wnt4 deletion was among the first mouse models that primarily affected the somatic cells of the embryonic ovary, where few, if any, of the genetic causes of morphological features were known at the time. Hence, in their analysis of the Wnt4 mutant phenotype, the authors were constrained by a rather limited armamentarium at their disposal [Vainio et al., 1999]. WNT4 loss resulted neither in the expression of Sertoli cell markers (e.g. Sox9, Dhh (Desert hedgehog), Amh (Anti-Müllerian hormone/Müllerian-inhibiting substance)) nor in morphologically identifiable sex cords in embryonic XX gonads. This indicated that the ovaries of Wnt4 mutants had not undergone a primary sex reversal leading to Sertoli cell development. However, other ovarian-specific genes were not known, and therefore one could not tell whether their expression was compromised. An observation that initially appeared to support a direct role for Wnt4 in ovarian development was ectopic steroidogenic gene expression in Wnt4 null ovaries. This led to the hypothesis that ovarian Wnt4 normally functions to suppress the development of Leydig cells [Vainio et al., 1999]. However, the follow-up analysis suggested that, rather than regulating a gonad-autonomous steroidogenic cell fate, WNT4 controls the migration of the endothelial and steroidogenic precursor cells [Hatano et al., 1996] into the ovary [Heikkila et al., 2002; Jeays-Ward et al., 2003]. Transgenic misexpression of Wnt4 in the embryonic testis did not suppress Leydig cell differentiation [Jeays-Ward et al., 2003]. Additionally, germ cells in XX Wnt4 mutant gonads were entering meiosis normally [Yao et al., 2004], indicating that the deletion of Wnt4 does not impair or reverse this essential embryonic function. In light of these findings, the commanding position for Wnt4 in ovarian development suddenly appeared less certain.

Uncovering the requirement for Wnt4 in antagonizing the male expression program constituted an important next step in the mechanistic understanding of ovarian development [Kim Y et al., 2006a]. Before the 2 opposing sex fates are established, the proteins that control them are already detectable in the mutually exclusive domains of the gonadal anlage, but in insufficient amounts to launch the programs. In the absence of WNT4, a malepromoting growth factor, fibroblast growth factor 9 (FGF9) becomes ectopically activated [Kim Y et al., 2006b]. FGF9 leads to a dramatic, but transient, spike in SOX9 expression in the E11.5-E12.0 XX Wnt4 null gonad. Similarly, loss of $\mathrm{Fgf9}$ expression results in the ectopic up-regulation of Wnt4 in the XY gonad. These find- 
ings provided the foundation for a 'tug-of-war' hypothesis, where the competition between 2 mutually antagonistic signals, namely Fgf9 (induced by Sry/Sox9) in the male and Wnt4 in the female, determines the outcome of the battle of the sexes. In the absence of Sry/Sox9/ Fgf9 expression, an increase in Wnt4 activity becomes sufficient for switching on the female pathway and for repressing testis development [reviewed in Kim and Capel, 2006].

\section{Fst and Bmp2}

Another important step in strengthening the commanding position for Wnt4 was the elucidation of the genetic interactions between Wnt4, Bmp2 (bone morphogenic protein), and Fst (follistatin). An astute observation by Capel and colleagues of coelomic vessel formation in $\mathrm{XX} \mathrm{Fst}{ }^{-/-}$embryos laid the foundation for the understanding of the epistatic relationship between these recently emerged ovarian-enriched genes [Yao et al., 2004]. Fst was one of the first genes that was isolated specifically based on its preferential expression in the embryonic ovary versus the testis [Menke and Page, 2002]. Fst expression was found to be absent in Wnt4 null embryonic gonads, while Wnt4 was expressed normally in $\mathrm{Fst}^{-}$ /- gonads. This observation placed Wnt4 upstream of Fst. Because the deletion of both genes led to a similar loss of germ cells, it was proposed that Fst acts as a downstream effector of Wnt4 to promote germ cell survival [Yao et al., 2004]. This work also documented the dimorphic (ovarybiased) expression of another gene, $B m p 2$, which is restricted to the layer of cells just beneath the coelomic layer at E12.5. The expression pattern of these genes positions Wnt4 at the top of the ovarian genetic cascade, as Bmp2 expression is also absent in Wnt4 null gonads but does not require Fst. Recently, it was suggested that while WNT4 is required to activate Fst expression, its maintenance depends on the cooperation between BMP2 and FOXL2 [Kashimada et al., 2011]. FST is expressed as multiple isoforms, and the absence of separate isoforms is sufficient to cause fertility defects in mice [Kimura et al., 2010, 2011]. Bmp2 knockout leads to early embryonic lethality [Zhang and Bradley, 1996]; the function of Bmp2 in ovarian development remains to be explored.

\section{Canonical WNT Signaling in Ovarian Development}

\section{Wnt Signaling: Its Friends and Foes}

The canonical Wnt/ $\beta$-catenin pathway is the best-understood signaling sequence initiated by WNT proteins.
It begins with a WNT ligand binding to a complex that is composed of a membrane-associated Frizzled (Fz) and an LDL-related receptor protein 5 (LRP5) or LRP6 co-receptor. This binding triggers a cascade of events culminating in the disassembly of the cytoplasmic $\beta$-catenin destruction complex that, in the absence of WNT, binds $\beta$ catenin and mediates its phosphorylation and subsequent degradation. Once free, $\beta$-catenin translocates into the cell nucleus where it participates in transcriptional regulation in partnership with the TCF/LEF family of transcription factors [for recent reviews, see Clevers, 2006; Grigoryan et al., 2008; van Amerongen and Nusse, 2009]. The function of this pathway in ovarian regulation has been recently reviewed [Zaytouni et al., 2011].

The activity of the canonical Wnt/ $\beta$-catenin pathway is modulated by several regulatory proteins that interact with either WNT molecules themselves or with their receptors [reviewed in Kikuchi et al., 2007]. These accessory proteins can serve to either enhance or suppress WNT signaling. DKK1, a member of the Dickkopf family of secreted proteins, acts as a designated antagonist of WNT-dependent activation. DKK1 inhibition of the canonical Wnt pathway is achieved through its ability to bind with high affinity to the LRP5 or LRP6 co-receptors, which prevents the formation of productive Fz-LRP5/6 receptor complexes [Bafico et al., 2001; Mao et al., 2001; Semenov et al., 2001]. In some settings, DKK1 appears to block Wnt signaling by simultaneously binding to LRP6 and to receptors of the Kremen family, thus inducing the internalization of the LRP6-Kremen complex [Mao et al., 2002], although this mechanism is unlikely to be universal. No other function for DKK1 other than its role as a Wnt pathway inhibitor has been described.

In contrast, R-spondins (RSPOs) represent a family of soluble proteins that act as co-activators of the canonical Wnt signaling pathway [Kim KA et al., 2006]. The biochemical mechanism of WNT modulation by RSPO proteins remains to be understood. It has been proposed that RSPOs activate Wnt/ $\beta$-catenin signaling by directly interacting with the WNT proteins, by facilitating the formation of the Fz/LRP receptor complex, or by directly binding to LRP receptors [Kazanskaya et al., 2004; Nam et al., 2006; Wei et al., 2007]. It has also been suggested that RSPOs could act through an alternative WNT-independent pathway to induce $\beta$-catenin activation [Kim et al., 2005; Gibbons et al., 2007]. Yet another study proposed that RSPO1 could be regulating Wnt signaling by preventing the DKK1/Kremen-mediated internalization of the LRP5/6 co-receptor [Binnerts et al., 2007]. Given the low levels of DKK1 expression in many tissues where 
RSPO1 is present, this last scenario could be uncommon. A mechanism that is likely to be more general postulates that RSPO proteins augment WNT activity by serving as ligands to the recently characterized LGR4/5/6 receptors [Carmon et al., 2011; de Lau et al., 2011; Glinka et al., 2011]. The resulting RSPO-LGR4/5/6 complexes are thought to promote a more efficient sequestration of the GSK3 enzyme that plays a key role in $\beta$-catenin inactivation [Taelman et al., 2010].

\section{RSPO in Ovarian Development}

The connection between RSPO1 and ovarian development first emerged through studies of a complete sex reversal in human XX patients. These patients developed testes and were harboring either a single-nucleotide insertion or a deletion in the RSPO1 gene [Vernole et al., 2000; Parma et al., 2006]. Rspol ovarian expression has been documented in several vertebrate species, prompting the suggestion that its ovary-determining role is highly conserved [Parma et al., 2006; Smith et al., 2008]. A homozygous splice donor site mutation in the RSPO1 gene resulted in an XX patient having both testicular and ovarian structures [Tomaselli et al., 2008]. Gene targeting in mice confirmed the role of the Rspol gene in ovarian development [Chassot et al., 2008; Tomizuka et al., 2008]. XX Rspo1 ${ }^{-/-}$animals developed ectopic coelomic vessels, persisting Wolffian ducts, and virilized external genitalia. Importantly, while ovarian development in these mice was dramatically impaired, a complete sex reversal was not observed. XX Rspo1 ${ }^{-/}$animals remained phenotypically female and developed functional follicles, with some retaining their fertility [Chassot et al., 2008; Tomizuka et al., 2008]. Overexpression of RSPO1 (goat RSPO1) did not interfere with male development, suggesting that RSPO1 gain-of-function is not sufficient to result in a sex reversal [Buscara et al., 2009]. While these experiments did not confirm a commanding role for RSPO1 in the ovarian developmental program, exploring the mechanism of RSPO1 function in ovarian differentiation was gratifying. In this respect, Chassot and colleagues [2008] were the first to compellingly demonstrate the presence of the active canonical Wnt $/ \beta$-catenin pathway in the ovary using the Axin $2^{\text {LacZ }}$ reporter strain and to examine the epistatic relationship between Rspol, $W n t 4$, and $\beta$-catenin (see below).

Canonical Wnt Signaling and Ovarian Development: What Took So Long?

While RSPO1 also did not quite fulfill its advanced billing as a universal ovarian-determining factor, studies in $R s p o 1^{-/}$mice provided incontrovertible evidence that the canonical Wnt/ $\beta$-catenin pathway is operating in the embryonic ovary [Chassot et al., 2008]. An identified role for another member of the Wnt pathway that is specifically implicated in canonical (vs. other) signaling intensified the search for evidence of the pathway's role in ovarian differentiation. Once again, in hindsight, the finding that Fst expression was absent in XX $W n t 4^{-/-}$gonads [Yao et al., 2004] made the next step (the connection to canonical $\beta$-catenin signaling) all but trivial - even without the 'bonus' Rspo1 hint. Indeed, in cultured cells the regulation of a Fst promoter by canonical $\beta$-catenin signaling has long been documented [Miyanaga and Shimasaki, 1993]. Moreover, mutating the putative TCF binding site in the Fst promoter led to a loss of response to the 'classical' canonical WNT3a ligand [Willert et al., 2002]. Given these quite explicit clues, one has to wonder why it took a few extra years before the Wnt/ $\beta$-catenin pathway's involvement as a key ovarian pathway came to light, as described below. Again, one can only speculate, but it is possible that the first barrier was our incomplete understanding of Wnt signaling just a few years ago [e.g. Bernard and Harley, 2007]. It was believed that Wnt4 belonged to a group of so-called 'non-canonical' Wnts that do not engage $\beta$-catenin [e.g. Shimizu et al., 1997]. Several years later, it became clear that the ability to engage a specific Wnt pathway is not an intrinsic property of a Wnt ligand, but rather any WNT molecule can activate $\beta$-catenin, provided an appropriate receptor is available [Mikels and Nusse, 2006]. Yet another obstacle was the limited ability to effectively monitor the presence of canonical $\beta$-catenin signaling in the developing gonad. The TOPGAL_LacZ cassette (the first Wnt/ $\beta$-catenin reporter that immediately became prevalent for inspecting the sites of $\beta$-catenin signaling in mice) [DasGupta and Fuchs, 1999] was inactive in developing gonads [Tevosian and Manuylov, 2008]. The strain that ultimately turned out to be informative for scoring the activity of the Wnt/ $\beta$-catenin pathway in the gonadal somatic cells, the Axin $2^{\text {LacZ }}$ strain [Yu et al., 2005], was not widely available until 2007. This more sensitive reporter unequivocally reveals the presence of canonical signaling in the somatic cells of developing ovaries but not in the testes [Chassot et al., 2008; Manuylov et al., 2008; Tevosian and Manuylov, 2008].

\section{Ctnnb1 ( $\beta$-Catenin, Catenin (Cadherin-Associated Protein), Beta 1)}

The genetic and biochemical evidence presented above suggested that both RSPO1 and WNT4 might ultimately 
exert their actions through the intracellular regulator, $\beta$ catenin [Mizusaki et al., 2003; Kim KA et al., 2006; Park et al., 2007; Chassot et al., 2008; Manuylov et al., 2008]. This set the stage for directly querying the involvement of $\beta$-catenin in ovarian development. Loss-of-function studies produced compelling evidence connecting the canonical Wnt pathway to ovarian differentiation [Manuylov et al., 2008; Liu et al., 2009]. A Cre recombinase, driven by the regulatory elements of the steroidogenic factor 1 (SF1)-encoding gene [Bingham et al., 2006], was an essential tool in these studies. To examine the role of $\beta$-catenin in ovarian development, a floxed $\beta$-catenin gene [Brault et al., 2001] was specifically inactivated in SF1-positive ovarian somatic cells. The XX SflCre; $\beta$ catenin ${ }^{\text {flox/flox }}$ mutants exhibited a comprehensive block in the embryonic ovarian gene expression program, similarly to the ones previously reported for Wnt4 and Rspol knockouts [Manuylov et al., 2008; Liu et al., 2009]. Likewise, when $\beta$-catenin is reintroduced in the absence of either Rspol or Wnt4, it rescues normal ovarian development [Chassot et al., 2008; Liu et al., 2009], suggesting that $\beta$-catenin is their common and main effector. While Wnt4 expression is lost in ovaries lacking $\beta$-catenin, Rspo1 expression remains unchanged, indicating that RSPO1 and $\beta$-catenin are both required for Wnt4 activation [Manuylov et al., 2008; Liu et al., 2009]; Wnt4 expression is activated by $\beta$-catenin stabilization in a positive feed-back regulatory loop [Chang et al., 2008]. In contrast, both Wnt4 expression and Axin2 ${ }^{\text {LacZ }}$ staining are lost in XX Rspo1 ${ }^{-/-}$mutants [Chassot et al., 2008], hinting that RSPO1 could serve as a common cofactor for the multiple Wnts that are reported to be present in the ovary [Cederroth et al., 2007]. In addition to the shared defects between Rspo1 and Wnt4 mutant animals, further evidence that these 2 genes may cooperate to promote the ovarian pathway came from a study of a human XY patient with male-to-female sex reversal. This patient carried a duplication in the region of chromosome 1 that contains both the WNT4 and RSPO1 loci [Elejalde et al., 1984; Jordan et al., 2001]. In vitro, both RSPO1 and WNT4 are able to activate $\beta$-catenin [Binnerts et al., 2007; Wei et al., 2007; Kim et al., 2008]; this activation likely relies on the recently described compound receptor complex that includes LGR receptors. A better understanding of the cooperation between RSPO1 and WNT4 should come from exploring the roles of the LGR4/5/6 family of receptors in the ovary.

The role of $\beta$-catenin was also compellingly demonstrated by gain-of-function experiments, where activation of this regulator in the SF1-positive cells resulted in partial XY sex reversal [Maatouk et al., 2008]. The mechanism of $ß$-catenin-induced sex reversal is not completely understood. It likely involves competition with Sox9 at the transcriptional or post-transcriptional level [Chang et al., 2008; Maatouk et al., 2008; for review, see Tevosian and Manuylov, 2008]. In support of this hypothesis, Sox 9 gain of function in the XX sex reversal model also suppresses Axin2 ${ }^{\text {LacZ }}$ expression [Chassot et al., 2008], and the stabilization of $\beta$-catenin in testes leads to a loss of both Sox9 and Amh expression [Chang et al., 2008].

\section{Ovarian Differentiation as a Shared Effort}

Mice lacking a functional Rspol develop ovarian defects similar to Wnt4 mutants, where ovarian development is impaired without a complete sex reversal [Chassot et al., 2008; Tomizuka et al., 2008]. Similarly, while loss of function experiments firmly established that canonical Wnt signaling is a prerequisite step for the gonadal commitment towards an ovarian fate, loss of $\beta$ catenin, while detrimental to ovarian development, did not result in the concomitant upregulation of testis-specific genes [Manuylov et al., 2008; reviewed in Tevosian and Manuylov, 2008; Liu et al., 2009, 2010]. These results once again reinforced the notion that ovarian differentiation engages more than one pathway and that all of them would have to be simultaneously disabled to shift the balance towards the male fate (fig. 1).

Given their joint involvement in regulating canonical Wnt signaling, the collaboration between WNT4 and RSPO1 was not all that surprising. In contrast, the Wnt4dependent genes and the ones that are regulated by FOXL2 appear to control complementary, rather than overlapping, pathways. The hypothesis that ovarian differentiation is autonomously guided by these 2 proteins (or rather pathways) is resting on several pieces of evidence and has been put forward most compellingly by Schlessinger and colleagues [e.g. Ottolenghi et al., 2007b; Schlessinger et al., 2010]. First, consistent with at least partial autonomy, Foxl2 and Wnt4 were each still expressed when the other gene was ablated [Ottolenghi et al., 2007b; Chassot et al., 2008; Manuylov et al., 2008]. Secondly, comparative analysis of gene expression in XX $\mathrm{Wnt}^{-{ }^{--}}$and Foxl2 $2^{-/-}$gonads by microarray suggested that WNT4 and FOXL2 regulate largely non-overlapping sets of genes. For example, the expression of genes with roles in glucose metabolism and protein synthesis was increased in Foxl2-null ovaries but decreased in Wnt4null ovaries; on the contrary, genes encoding proteins involved in cell-cell interactions and neuronal-like pathways were downregulated in Foxl2-null ovaries but up- 
regulated in the absence of Wnt4 [Garcia-Ortiz et al., 2009]. It has also been demonstrated that in goat, gRSPO1 (which is tightly linked to WNT4/ $\beta$-catenin signaling) and gFOXL2 are localized to spatially separate ovarian domains [Kocer et al., 2008]; this distribution has yet to be tested in other species. Finally, and most importantly, while Foxl2 or Wnt4 alone may not be sufficient to determine ovarian fate, analysis of mice with deficiencies in both Foxl2 and Wnt4 lent support to the notion that the 2 factors may act in a cooperative manner to establish a female sexual identity [Ottolenghi et al., 2007b]. Deletion of both Foxl2 and Wnt4 resulted in testis differentiation in XX mice, including the formation of testis cords, the expression of Sox9 and Amh/Mis, and the differentiation of germ cells into spermatogonia. Still, the sex-reversal phenotype only becomes pronounced near the time of birth and is not fully penetrant, with ovarian somatic cells and oocytes still present. While the 'two-hit' mechanism for the sexual determination of the ovary appears quite persuasive, the activity of the Foxl2 ${ }^{\mathrm{LacZ}}$ reporter gene [Schmidt et al., 2004] is comparable between the Wnt4 null mutant and the double Wnt4 ${ }^{-/}$; Foxl2 $2^{-/-}$ knockout [Uhlenhaut et al., 2009]. This observation led the authors to conclude that Wnt4 does not synergize with Foxl2 during embryonic development [Uhlenhaut et al., 2009].

\section{Integrity of the Ovarian Fate}

The embryonic development of the Foxl2 mutant ovary proceeds apparently as normal; however, shortly after the time of birth, Foxl2 null gonads begin drifting towards testis differentiation in what was initially described as a secondary partial sex reversal [Ottolenghi et al., 2005, 2007a]. The critical role of Foxl2 in maintaining ovarian identity has been recently confirmed by an elegant study that revealed a novel function of this gene [Uhlenhaut et al., 2009]. The inducible deletion of Foxl 2 in adult ovarian follicles leads to the upregulation of Sox 9 , the transdifferentiation of granulosa cells into Sertoli cells, and the appearance of testis structures and functional testis cell types. Foxl 2 deletion also leads to an acute demise of ovarian gene expression with concomitant oocyte loss. To perform its guardian role in maintaining the integrity of the female 'makeup', FOXL2 serves as a direct repressor for Sox9 through its gonad-specific TESCO enhancer module. In this repression, FOXL2 is assisted by estrogen receptors. Both FOXL2 and estrogen regulation are required to sustain the granulosa cell phenotype, as granu-

Genetic Control of Ovarian Development losa cell transdifferentiation into Sertoli cells has also been observed in the adult ovaries of the estrogen receptor alpha and beta double knockout $(\mathrm{ER} \alpha \beta \mathrm{KO})$ and the aromatase knockout mice [Dupont et al., 2000, 2003; Britt et al., 2004]. While undoubtedly a part of FOXL2 custodial duties, the ability to suppress Sox9 is not likely to be the only sentry point for FOXL2-dependent ovarian fate maintenance. Sox9 is dispensable for testis differentiation once the sex determination mission is accomplished [Chang et al., 2008; Barrionuevo et al., 2009] and other genes (e.g. Sox8 [Chaboissier et al., 2004] or Dmrt1 [Matson et al., 2011], see below) may constitute equally important targets that are in need of FOXL2 repression.

While the inherent lability of the adult ovarian state was arguably predictable [e.g. Ottolenghi et al., 2007a], the recent discovery of extensive reprogramming in the testis upon loss of Dmrt1 was quite unexpected [Matson et al., 2011]. These results suggest that an antagonism between the transcription factors FOXL2 and DMRT1 is critical to uphold the stability of the differentiated gonadal state of the adult. These 2 groundbreaking publications [Uhlenhaut et al., 2009; Matson et al., 2011] expose a long-anticipated plasticity in the gonadal differentiation of both sexes.

Another enduring problem that was valiantly confronted by Uhlenhaut et al. [2009] concerned the oocytes' role in the postnatal transdifferentiation of granulosa cells into Sertoli cells. In contrast to the continuous FOXL2 expression that is necessary for maintaining female-specific gene expression and ovarian cell fate, the targeted genetic ablation of oocytes proved them to be dispensable for the carrying out of these duties. While germ cell ablation does not induce granulosa cell transdifferentiation, this fact alone does not necessarily prevent germ cells from having a say in somatic cell development, and oogonia or oocytes likely possess some antitestis properties [Yao et al., 2003].

\section{Concluding Remarks}

We still have much to learn about gonadal development, and the recent reports on the remarkable ability of ovaries, and now testes, to transdifferentiate are yet further proof that surprising discoveries are on their way. Upon mentioning transdifferentiation, one is compelled to address 'the other' subject now equally in vogue: microRNA. Several groups have reported abnormal postnatal ovarian development upon Dicer ablation in mice using Amhr2-Cre [Hong et al., 2008; Nagaraja et al., 2008; 
Lei et al., 2010], and we are bound to learn more about specific microRNAs that control ovarian function. However, the extent of microRNA involvement in granulosa cell differentiation during embryogenesis appears limited, as Dicer ablation using the SF1-driven Cre (Sf1Cre) did not produce a notable ovarian phenotype [Huang and Yao, 2010].

The powerful genetic approaches available in mice will undoubtedly keep them as the species of choice for reproductive research aimed at hunting for new genes that have roles in sexual development [e.g. Munger et al., 2009]. Additionally, mice with inducible gonad-specific Cre recombinases should permit the re-examining of the previously known genes that have already been implicated in sexual development, for example, in cases where the null phenotypes show defects in gonad formation, rather than subsequent sexual differentiation. Still, even the most ardent murine aficionado has to keep the perspective that mice cannot tell us everything about ovarian organogenesis in other species, including humans [Jimenez, 2009]. Here too, whole genome sequencing technologies are bound to uncover novel sex determination genes in patients with DSD [Arboleda and Vilain, 2011]. The epigenetic regulation of sexual development remains largely unexplored and will likely be a fruitful field for the future.

\section{Acknowledgements}

I would like to thank Maria Padua and Ramji Bhandari for their thoughtful comments on this manuscript and the NIH for their continuous support (HD042751).

\section{References}

Albrecht KH, Eicher EM: Evidence that Sry is expressed in pre-Sertoli cells and Sertoli and granulosa cells have a common precursor. Dev Biol 240:92-107 (2001).

-Arboleda VA, Vilain E: The evolution of the search for novel genes in mammalian sex determination: from mice to men. Mol Genet Metab 104:67-71 (2011).

- Bafico A, Liu G, Yaniv A, Gazit A, Aaronson SA: Novel mechanism of Wnt signalling inhibition mediated by Dickkopf-1 interaction with LRP6/Arrow. Nat Cell Biol 3:683-686 (2001).

Barrionuevo F, Bagheri-Fam S, Klattig J, Kist R, Taketo MM, et al: Homozygous inactivation of Sox9 causes complete XY sex reversal in mice. Biol Reprod 74:195-201 (2006).

-Barrionuevo F, Georg I, Scherthan H, Lecureuil C, Guillou F, et al: Testis cord differentiation after the sex determination stage is independent of Sox 9 but fails in the combined absence of Sox 9 and Sox8. Dev Biol 327:301-312 (2009).

Bernard P, Harley VR: Wnt4 action in gonadal development and sex determination. Int $\mathrm{J}$ Biochem Cell Biol 39:31-43 (2007).

- Beverdam A, Koopman P: Expression profiling of purified mouse gonadal somatic cells during the critical time window of sex determination reveals novel candidate genes for human sexual dysgenesis syndromes. Hum Mol Genet 15:417-431 (2006).

-Biason-Lauber A, Konrad D, Navratil F, Schoenle EJ: A WNT4 mutation associated with Müllerian-duct regression and virilization in a 46,XX woman. N Engl J Med 351:792798 (2004).
Biason-Lauber A, De Filippo G, Konrad D, Scarano G, Nazzaro A, Schoenle EJ: WNT4 deficiency - a clinical phenotype distinct from the classic Mayer-Rokitansky-KusterHauser syndrome: a case report. Hum Reprod 22:224-229 (2007).

- Bingham NC, Verma-Kurvari S, Parada LF, Parker KL: Development of a steroidogenic factor $1 /$ Cre transgenic mouse line. Genesis 44:419-424 (2006).

Binnerts ME, Kim KA, Bright JM, Patel SM, Tran $\mathrm{K}$, et al: R-Spondin1 regulates Wnt signaling by inhibiting internalization of LRP6. Proc Natl Acad Sci USA 104:14700-14705 (2007).

Bishop CE, Whitworth DJ, Qin Y, Agoulnik AI, Agoulnik IU, et al: A transgenic insertion upstream of Sox9 is associated with dominant XX sex reversal in the mouse. Nat Genet 26:490-494 (1999).

Brault V, Moore R, Kutsch S, Ishibashi M, Rowitch $\mathrm{DH}$, et al: Inactivation of the betacatenin gene by Wnt1-Cre-mediated deletion results in dramatic brain malformation and failure of craniofacial development. Development 128:1253-1264 (2001).

Brennan J, Capel B: One tissue, two fates: molecular genetic events that underlie testis versus ovary development. Nat Rev Genet 5: 509-521 (2004).

- Britt KL, Stanton PG, Misso M, Simpson ER, Findlay JK: The effects of estrogen on the expression of genes underlying the differentiation of somatic cells in the murine gonad. Endocrinology 145:3950-3960 (2004).

Burgoyne PS: Role of mammalian Y chromosome in sex determination. Philos Trans $\mathrm{R}$ Soc Lond B Biol Sci 322:63-72 (1988).
Burgoyne PS, Buehr M, McLaren A: XY follicle cells in ovaries of XX-XY female mouse chimaeras. Development 104:683-688 (1988).

Buscara L, Montazer-Torbati F, Chadi S, Auguste A, Laubier J, et al: Goat RSPO1 over-expression rescues sex-reversal in Rspo1-knockout XX mice but does not perturb testis differentiation in $\mathrm{XY}$ or sex-reversed $\mathrm{XX}$ mice. Transgenic Res 18:649-654 (2009).

Byskov AG: Differentiation of mammalian embryonic gonad. Physiol Rev 66:71-117. (1986).

Byskov AG, Nielsen M: Ontogeny of the mammalian ovary, in Trounson AO, Gosden RG (eds): Biology and Pathology of the Oocyte, pp 13-28 (Cambridge University Press, New York 2003).

Capel B: The battle of the sexes. Mech Dev 92: 89-103 (2000).

Capel B: R-spondin1 tips the balance in sex determination. Nat Genet 38:1233-1234 (2006).

Carmon KS, Gong X, Lin Q, Thomas A, Liu Q: $\mathrm{R}$-spondins function as ligands of the orphan receptors LGR4 and LGR5 to regulate Wnt/beta-catenin signaling. Proc Natl Acad Sci USA 108:11452-11457 (2011).

Cederroth CR, Pitetti JL, Papaioannou MD, Nef $S$ : Genetic programs that regulate testicular and ovarian development. Mol Cell Endocrinol 265-266:3-9 (2007).

- Chaboissier MC, Kobayashi A, Vidal VI, Lutzkendorf S, van de Kant HJ, et al: Functional analysis of Sox8 and Sox 9 during sex determination in the mouse. Development 131: 1891-1901 (2004).

-Chang H, Gao F, Guillou F, Taketo MM, Huff V, Behringer RR: Wt1 negatively regulates betacatenin signaling during testis development. Development 135:1875-1885 (2008). 
Chassot AA, Ranc F, Gregoire EP, Roepers-Gajadien HL, Taketo MM, et al: Activation of beta-catenin signaling by Rspol controls differentiation of the mammalian ovary. Hum Mol Genet 17:1264-1277 (2008).

Clevers H: Wnt/beta-catenin signaling in development and disease. Cell 127:469-480 (2006).

Combes AN, Spiller C, Koopman P: Sex determination and gonadal development; in Verlhac MH, Villeneuve A (eds): Oogenesis: The Universal Process, pp 27-79 (John Wiley \& Sons, Ltd, Chichester 2010).

-Crisponi L, Deiana M, Loi A, Chiappe F, Uda M, et al: The putative forkhead transcription factor FOXL2 is mutated in blepharophimosis/ptosis/epicanthus inversus syndrome. Nat Genet 27:159-166 (2001).

DasGupta R, Fuchs E: Multiple roles for activated LEF/TCF transcription complexes during hair follicle development and differentiation. Development 126:4557-4568 (1999).

$\checkmark$ de Lau W, Barker N, Low TY, Koo BK, Li VS, et al: LGR5 homologues associate with Wnt receptors and mediate R-spondin signalling. Nature 476:293-297 (2011).

Dupont S, Krust A, Gansmuller A, Dierich A, Chambon P, Mark M: Effect of single and compound knockouts of estrogen receptors alpha (ERalpha) and beta (ERbeta) on mouse reproductive phenotypes. Development 127: 4277-4291 (2000).

>Dupont S, Dennefeld C, Krust A, Chambon P, Mark M: Expression of Sox 9 in granulosa cells lacking the estrogen receptors, ERalpha and ERbeta. Dev Dyn 226:103-106 (2003).

-Edson MA, Nagaraja AK, Matzuk MM: The mammalian ovary: from genesis to revelation. Endocr Rev 30:624-712 (2009).

-Eicher EM, Washburn LL: Inherited sex reversal in mice: identification of a new primary sexdetermining gene. J Exp Zool 228:297-304 (1983).

Eicher EM, Washburn LL: Genetic control of primary sex determination in mice. Annu Rev Genet 20:327-360 (1986).

-Eicher EM, Washburn LL, Whitney JB 3rd, Morrow KE: Mus poschiavinus $\mathrm{Y}$ chromosome in the C57BL/6J murine genome causes sex reversal. Science 217:535-537 (1982).

-Elejalde BR, Opitz JM, de Elejalde MM, Gilbert EF, Abellera M, et al: Tandem dup (1p) within the short arm of chromosome 1 in a child with ambiguous genitalia and multiple congenital anomalies. Am J Med Genet 17:723730 (1984).

-Garcia-Ortiz JE, Pelosi E, Omari S, Nedorezov T, Piao Y, et al: Foxl2 functions in sex determination and histogenesis throughout mouse ovary development. BMC Dev Biol 9:36 (2009).

Gibbons C, Dackor R, Dunworth W, Fritz-Six K, Caron KM: Receptor activity-modifying proteins: RAMPing up adrenomedullin signaling. Mol Endocrinol 21:783-796 (2007).
Glinka A, Dolde C, Kirsch N, Huang YL, Kazanskaya O, et al: LGR4 and LGR5 are R-spondin receptors mediating Wnt/beta-catenin and Wnt/PCP signalling. EMBO Rep 12:10551061 (2011).

Gondos B, Zamboni L: Ovarian development: the functional importance of germ cell interconnections. Fertil Steril 20:176-189 (1969).

Goodfellow PN, Darling SM: Genetics of sex determination in man and mouse. Development 102:251-258 (1988).

Goodfellow PN, Lovell BR: SRY and sex determination in mammals. Annu Rev Genet 27:7192 (1993)

Grigoryan T, Wend P, Klaus A, Birchmeier W: Deciphering the function of canonical Wnt signals in development and disease: conditional loss- and gain-of-function mutations of beta-catenin in mice. Genes Dev 22:23082341 (2008).

Gubbay J, Collignon J, Koopman P, Capel B, Economou A, et al: A gene mapping to the sex-determining region of the mouse $\mathrm{Y}$ chromosome is a member of a novel family of embryonically expressed genes. Nature 346: 245-250 (1990).

Hatano O, Takakusu A, Nomura M, Morohashi $\mathrm{K}$ : Identical origin of adrenal cortex and gonad revealed by expression profiles of Ad4BP/SF-1. Genes Cells 1:663-671 (1996).

Heikkila M, Peltoketo H, Leppaluoto J, Ilves M, Vuolteenaho O, Vainio S: Wnt4 deficiency alters mouse adrenal cortex function, reducing aldosterone production. Endocrinology 143:4358-4365 (2002).

-Hong X, Luense LJ, McGinnis LK, Nothnick WB, Christenson LK: Dicer1 is essential for female fertility and normal development of the female reproductive system. Endocrinology 149:6207-6212 (2008).

Huang CC, Yao HH: Inactivation of Dicer1 in Steroidogenic Factor 1-positive cells reveals tissue-specific requirement for Dicer1 in adrenal, testis, and ovary. BMC Dev Biol 10:66 (2010).

Huang $\mathrm{H}$, He X: Wnt/beta-catenin signaling: new (and old) players and new insights. Curr Opin Cell Biol 20:119-125 (2008).

Ito M, Yokouchi K, Yoshida K, Kano K, Naito K, et al: Investigation of the fate of Sry-expressing cells using an in vivo Cre/loxP system. Dev Growth Differ 48:41-47 (2006).

Jeays-Ward K, Hoyle C, Brennan J, Dandonneau M, Alldus G, et al: Endothelial and steroidogenic cell migration are regulated by WNT4 in the developing mammalian gonad. Development 130:3663-3670 (2003).

Jimenez R: Ovarian organogenesis in mammals: mice cannot tell us everything. Sex Dev 3: 291-301 (2009).

Jordan BK, Mohammed M, Ching ST, Delot E, Chen XN, et al: Up-regulation of WNT4 signaling and dosage-sensitive sex reversal in humans. Am J Hum Genet 68:1102-1109 (2001).
Jordan BK, Shen JH, Olaso R, Ingraham HA, Vilain E: Wnt4 overexpression disrupts normal testicular vasculature and inhibits testosterone synthesis by repressing steroidogenic factor 1/beta-catenin synergy. Proc Natl Acad Sci USA 100:10866-10871 (2003).

Jorgensen JS, Gao L: Irx3 is differentially up-regulated in female gonads during sex determination. Gene Expr Patterns 5:756-762 (2005).

Jost A: A new look at the mechanisms controlling sex differentiation in mammals. Johns Hopkins Med J 130:38-53 (1972).

Kashimada K, Pelosi E, Chen H, Schlessinger D, Wilhelm D, Koopman P: FOXL2 and BMP2 act cooperatively to regulate follistatin gene expression during ovarian development. Endocrinology 152:272-280 (2011).

Katoh M: WNT/PCP signaling pathway and human cancer (review). Oncol Rep 14:15831588 (2005)

Kazanskaya O, Glinka A, del Barco Barrantes I, Stannek P, Niehrs C, Wu W: R-Spondin2 is a secreted activator of Wnt/beta-catenin signaling and is required for Xenopus myogenesis. Dev Cell 7:525-534 (2004).

Kikuchi A, Yamamoto H, Kishida S: Multiplicity of the interactions of Wnt proteins and their receptors. Cell Signal 19:659-671 (2007).

Kim KA, Kakitani M, Zhao J, Oshima T, Tang T, et al: Mitogenic influence of human R-spondin 1 on the intestinal epithelium. Science 309:1256-1259 (2005)

- Kim KA, Zhao J, Andarmani S, Kakitani M, Oshima T, et al: R-Spondin proteins: a novel link to beta-catenin activation. Cell Cycle 5:23-26 (2006).

Kim KA, Wagle M, Tran K, Zhan X, Dixon MA, et al: R-Spondin family members regulate the Wnt pathway by a common mechanism. Mol Biol Cell 19:2588-2596 (2008).

Kim Y, Capel B: Balancing the bipotential gonad between alternative organ fates: a new perspective on an old problem. Dev Dyn 235: 2292-2300 (2006).

Kim Y, Kobayashi A, Sekido R, DiNapoli L, Brennan J, et al: Fgf9 and Wnt4 act as antagonistic signals to regulate mammalian sex determination. PLoS Biol 4:e187 (2006).

Kimura F, Sidis Y, Bonomi L, Xia Y, Schneyer A The follistatin-288 isoform alone is sufficient for survival but not for normal fertility in mice. Endocrinology 151:1310-1319 (2010).

Kimura F, Bonomi LM, Schneyer AL: Follistatin regulates germ cell nest breakdown and primordial follicle formation. Endocrinology 152:697-706 (2011).

Kocer A, Pinheiro I, Pannetier M, Renault L, Parma P, et al: R-spondin1 and FOXL2 act into two distinct cellular types during goat ovarian differentiation. BMC Dev Biol 8:36 (2008).

Kohn AD, Moon RT: Wnt and calcium signaling: beta-catenin-independent pathways. Cell Calcium 38:439-446 (2005). 
Koopman P, Gubbay J, Vivian N, Goodfellow P, Lovell BR: Male development of chromosomally female mice transgenic for Sry. Nature 351:117-121 (1991).

Lee HJ, Pazin DE, Kahlon RS, Correa SM, Albrecht $\mathrm{KH}$ : Novel markers of early ovarian pre-granulosa cells are expressed in an Srylike pattern. Dev Dyn 238:812-825 (2008).

- Lei L, Jin S, Gonzalez G, Behringer RR, Woodruff TK: The regulatory role of Dicer in folliculogenesis in mice. Mol Cell Endocrinol 315:63-73 (2010)

Liu CF, Bingham N, Parker K, Yao HH: Sex-specific roles of beta-catenin in mouse gonadal development. Hum Mol Genet 18:405-417 (2009).

Liu CF, Liu C, Yao HH: Building pathways for ovary organogenesis in the mouse embryo. Curr Top Dev Biol 90:263-290 (2010).

Loffler KA, Zarkower D, Koopman P: Etiology of ovarian failure in blepharophimosis ptosis epicanthus inversus syndrome: FOXL2 is a conserved, early-acting gene in vertebrate ovarian development. Endocrinology 144: 3237-3243 (2003).

Ma Q, Zhou B, Pu WT: Reassessment of Isl1 and Nkx2-5 cardiac fate maps using a Gata4based reporter of Cre activity. Dev Biol 323: 98-104 (2008).

Maatouk DM, DiNapoli L, Alvers A, Parker KL, Taketo MM, Capel B: Stabilization of betacatenin in XY gonads causes male-to-female sex-reversal. Hum Mol Genet 17:2949-2955 (2008).

-Mandel H, Shemer R, Borochowitz ZU, Okopnik $M$, Knopf C, et al: SERKAL syndrome: an autosomal-recessive disorder caused by a loss-of-function mutation in WNT4. Am J Hum Genet 82:39-47 (2008).

-Manuylov NL, Smagulova FO, Leach L, Tevosian SG: Ovarian development in mice requires the GATA4-FOG2 transcription complex. Development 135:3731-3743 (2008).

- Mao B, Wu W, Li Y, Hoppe D, Stannek P, et al: LDL-receptor-related protein 6 is a receptor for Dickkopf proteins. Nature 411:321-325 (2001).

- Mao B, Wu W, Davidson G, Marhold J, Li M, et al: Kremen proteins are Dickkopf receptors that regulate Wnt/beta-catenin signalling. Nature 417:664-667 (2002).

Matson CK, Murphy MW, Sarver AL, Griswold MD, Bardwell VJ, Zarkower D: DMRT1 prevents female reprogramming in the postnatal mammalian testis. Nature 476:101-104 (2011).

McElreavey K, Vilain E, Abbas N, Herskowitz I, Fellous M: A regulatory cascade hypothesis for mammalian sex determination: $S R Y$ represses a negative regulator of male development. Proc Natl Acad Sci USA 90:3368-3372 (1993).

-McLaren A: Development of the mammalian gonad: the fate of the supporting cell lineage. Bioessays 13:151-156 (1991).
McLaren A, Southee D: Entry of mouse embryonic germ cells into meiosis. Dev Biol 187: 107-113 (1997)

-Menke DB, Page DC: Sexually dimorphic gene expression in the developing mouse gonad. Gene Expr Patterns 2:359-367 (2002).

Menke DB, Koubova J, Page DC: Sexual differentiation of germ cells in XX mouse gonads occurs in an anterior-to-posterior wave. Dev Biol 262:303-312 (2003).

Mikels AJ, Nusse R: Purified WNT5a protein activates or inhibits beta-catenin-TCF signaling depending on receptor context. PLoS Biol 4:e115 (2006)

Miyanaga K, Shimasaki S: Structural and functional characterization of the rat follistatin (activin-binding protein) gene promoter. Mol Cell Endocrinol 92:99-109 (1993).

-Mizusaki H, Kawabe K, Mukai T, Ariyoshi E, Kasahara M, et al: Daxl (dosage-sensitive sex reversal-adrenal hypoplasia congenita critical region on the $\mathrm{X}$ chromosome, gene 1) gene transcription is regulated by Wnt4 in the female developing gonad. Mol Endocrinol 17:507-519 (2003).

Molkentin JD: The zinc finger-containing transcription factors GATA-4, -5, and -6. Ubiquitously expressed regulators of tissue-specific gene expression. J Biol Chem 275: 38949-38952 (2000).

Morceau F, Schnekenburger M, Dicato M, Diederich M: GATA-1: friends, brothers, and coworkers. Ann N Y Acad Sci 1030:537-554 (2004).

-Mork L, Maatouk DM, McMahon JA, Guo JJ, Zhang P, et al: Temporal differences in granulosa cell specification in the ovary reflect distinct follicle fates in mice. Biol Reprod 86: 37 (2011).

Munger SC, Aylor DL, Syed HA, Magwene PM, Threadgill DW, Capel B: Elucidation of the transcription network governing mammalian sex determination by exploiting strainspecific susceptibility to sex reversal. Genes Dev 23:2521-2536 (2009).

Nagaraja AK, Andreu-Vieyra C, Franco HL, Ma L, Chen R, et al: Deletion of Dicer in somatic cells of the female reproductive tract causes sterility. Mol Endocrinol 22:2336-2352 (2008).

Nam JS, Turcotte TJ, Smith PF, Choi S, Yoon JK: Mouse cristin/R-spondin family proteins are novel ligands for the Frizzled 8 and LRP6 receptors and activate beta-catenin-dependent gene expression. J Biol Chem 281:1324713257 (2006)

- Nef S, Schaad O, Stallings NR, Cederroth CR, Pitetti JL, et al: Gene expression during sex determination reveals a robust female genetic program at the onset of ovarian development. Dev Biol 287:361-377 (2005)

Novak A, Guo C, Yang W, Nagy A, Lobe CG: Z/ EG, a double reporter mouse line that expresses enhanced green fluorescent protein upon Cre-mediated excision. Genesis 28: 147-155 (2000).
Ottolenghi C, Omari S, Garcia-Ortiz JE, Uda M, Crisponi L, et al: Foxl2 is required for commitment to ovary differentiation. Hum Mol Genet 14:2053-2062 (2005).

-Ottolenghi C, Uda M, Crisponi L, Omari S, Cao A, et al: Determination and stability of sex. BioEssays 29:15-25 (2007a).

-Ottolenghi C, Pelosi E, Tran J, Colombino M, Douglass E, et al: Loss of Wnt4 and Foxl2 leads to female-to-male sex reversal extending to germ cells. Hum Mol Genet 16:27952804 (2007b).

-Pailhoux E, Vigier B, Chaffaux S, Servel N, Taourit S, et al: A 11.7-kb deletion triggers intersexuality and polledness in goats. Nat Genet 29:453-458 (2001)

Palmer SJ, Burgoyne PS: In situ analysis of fetal, prepuberal and adult XX-XY chimaeric mouse testes: Sertoli cells are predominantly, but not exclusively, XY. Development 112: 265-268 (1991).

- Park JS, Valerius MT, McMahon AP: Wnt/betacatenin signaling regulates nephron induction during mouse kidney development. Development 134:2533-2539 (2007)

Parma P, Radi O, Vidal V, Chaboissier MC, Dellambra E, et al: R-spondin1 is essential in sex determination, skin differentiation and malignancy. Nat Genet 38:1304-1309 (2006).

Patient RK, McGhee JD: The GATA family (vertebrates and invertebrates). Curr Opin Genet Dev 12:416-422 (2002)

-Pepling ME, Spradling AC: Female mouse germ cells form synchronously dividing cysts. Development 125:3323-3328 (1998).

Richards JS, Pangas SA: The ovary: basic biology and clinical implications. J Clin Invest 120: 963-972 (2010).

-Schlessinger D, Garcia-Ortiz JE, Forabosco A, Uda M, Crisponi L, Pelosi E: Determination and stability of gonadal sex. J Androl 31:1625 (2010).

-Schmidt D, Ovitt CE, Anlag K, Fehsenfeld S, Gredsted L, et al: The murine winged-helix transcription factor Foxl2 is required for granulosa cell differentiation and ovary maintenance. Development 131:933-942 (2004).

- Sekido R, Lovell-Badge R: Sex determination involves synergistic action of SRY and SF1 on a specific Sox 9 enhancer. Nature 453:930-934 (2008)

Semenov MV, Tamai K, Brott BK, Kuhl M, Sokol S, He X: Head inducer Dickkopf-1 is a ligand for Wnt coreceptor LRP6. Curr Biol 11:951961 (2001).

Shimizu H, Julius MA, Giarre M, Zheng Z, Brown AM, Kitajewski J: Transformation by WNT family proteins correlates with regulation of beta-catenin. Cell Growth Differ 8: 1349-1358 (1997).

Sinclair AH, Berta P, Palmer MS, Hawkins JR, Griffiths BL, et al: A gene from the human sex-determining region encodes a protein with homology to a conserved DNA-binding motif. Nature 346:240-244 (1990). 
-Small CL, Shima JE, Uzumcu M, Skinner MK, Griswold MD: Profiling gene expression during the differentiation and development of the murine embryonic gonad. Biol Reprod 72:492-501 (2005).

- Smith CA, Shoemaker CM, Roeszler KN, Queen J, Crews D, Sinclair AH: Cloning and expression of R-Spondin1 in different vertebrates suggests a conserved role in ovarian development. BMC Dev Biol 8:72 (2008).

-Stark K, Vainio S, Vassileva G, McMahon AP: Epithelial transformation of metanephric mesenchyme in the developing kidney regulated by Wnt4. Nature 372:679-683 (1994).

- Swain A, Lovell-Badge R: Mammalian sex determination: a molecular drama. Genes Dev 13: 755-767 (1999).

- Taelman VF, Dobrowolski R, Plouhinec JL, Fuentealba LC, Vorwald PP, et al: Wnt signaling requires sequestration of glycogen synthase kinase 3 inside multivesicular endosomes. Cell 143:1136-1148 (2010).

Tevosian SG, Manuylov NL: To $\beta$ or not to $\beta$ : canonical beta-catenin signaling pathway and ovarian development. Dev Dyn 237:36723680 (2008).

-Tomaselli S, Megiorni F, De Bernardo C, Felici A, Marrocco G, et al: Syndromic true hermaphroditism due to an R-spondin1 (RSPO1) homozygous mutation. Hum Mutat 29:220226 (2008).

- Tomizuka K, Horikoshi K, Kitada R, Sugawara Y, Iba Y, et al: R-spondin1 plays an essential role in ovarian development through positively regulating Wnt4 signaling. Hum Mol Genet 17:1278-1291 (2008).

- Townes PL, Muechler EK: Blepharophimosis, ptosis, epicanthus inversus, and primary amenorrhea. A dominant trait. Arch Ophthalmol 97:1664-1666 (1979).
Uda M, Ottolenghi C, Crisponi L, Garcia JE, Deiana M, et al: Foxl2 disruption causes mouse ovarian failure by pervasive blockage of follicle development. Hum Mol Genet 13:11711181 (2004).

Uhlenhaut NH, Treier M: Forkhead transcription factors in ovarian function. Reproduction (2011).

Uhlenhaut NH, Jakob S, Anlag K, Eisenberger T, Sekido R, et al: Somatic sex reprogramming of adult ovaries to testes by FOXL2 ablation. Cell 139:1130-1142 (2009).

Vainio S, Heikkila M, Kispert A, Chin N, McMahon AP: Female development in mammals is regulated by Wnt4 signalling. Nature 397: 405-409 (1999).

van Amerongen R, Nusse R: Towards an integrated view of Wnt signaling in development. Development 136:3205-3214 (2009).

Vernole P, Terrinoni A, Didona B, De Laurenzi V, Rossi P, et al: An SRY-negative XX male with Huriez syndrome. Clin Genet 57:61-66 (2000).

Vidal VP, Chaboissier MC, de Rooij DG, Schedl A: Sox9 induces testis development in $\mathrm{XX}$ transgenic mice. Nat Genet 28:216-217 (2001).

-Viger RS, Guittot SM, Anttonen M, Wilson DB, Heikinheimo M: Role of the GATA family of transcription factors in endocrine development, function, and disease. Mol Endocrinol 22:781-798 (2008).

Vooijs M, Jonkers J, Berns A: A highly efficient ligand-regulated Cre recombinase mouse line shows that LoxP recombination is position dependent. EMBO Rep 2:292-297 (2001).

Wang D, Kobayashi T, Zhou L, Nagahama Y: Molecular cloning and gene expression of Foxl2 in the Nile tilapia, Oreochromis niloticus. Biochem Biophys Res Commun 320:8389 (2004).

-Washburn LL, Eicher EM: Sex reversal in XY mice caused by dominant mutation on chromosome 17. Nature 303:338-340 (1983).
Wei Q, Yokota C, Semenov MV, Doble B, Woodgett J, He X: R-spondin 1 is a high affinity ligand for LRP6 and induces LRP6 phosphorylation and beta-catenin signaling. J Biol Chem 282:15903-15911 (2007).

-Wilhelm D, Martinson F, Bradford S, Wilson MJ, Combes AN, et al: Sertoli cell differentiation is induced both cell-autonomously and through prostaglandin signaling during mammalian sex determination. Dev Biol 287:111-124 (2005).

-Wilhelm D, Palmer S, Koopman P: Sex determination and gonadal development in mammals. Physiol Rev 87:1-28 (2007).

Wilhelm D, Washburn LL, Truong V, Fellous M, Eicher EM, Koopman P: Antagonism of the testis- and ovary-determining pathways during ovotestis development in mice. Mech Dev 126:324-336 (2009).

-Willert J, Epping M, Pollack JR, Brown PO, Nusse R: A transcriptional response to Wnt protein in human embryonic carcinoma cells. BMC Dev Biol 2:8 (2002).

Yao HH, DiNapoli L, Capel B: Meiotic germ cells antagonize mesonephric cell migration and testis cord formation in mouse gonads. Development 130:5895-5902 (2003).

- Yao HH, Matzuk MM, Jorgez CJ, Menke DB, Page DC, et al: Follistatin operates downstream of Wnt4 in mammalian ovary organogenesis. Dev Dyn 230:210-215 (2004).

-Yu HM, Jerchow B, Sheu TJ, Liu B, Costantini F, et al: The role of Axin2 in calvarial morphogenesis and craniosynostosis. Development 132:1995-2005 (2005).

Zaytouni T, Efimenko EE, Tevosian SG: GATA transcription factors in the developing reproductive system. Adv Genet 76:93-134 (2011).

Zhang H, Bradley A: Mice deficient for BMP2 are nonviable and have defects in amnion/chorion and cardiac development. Development 122:2977-2986 (1996). 